University of Nebraska - Lincoln

DigitalCommons@University of Nebraska - Lincoln

Papers in Biotechnology

Chemical and Biomolecular Engineering

Research and Publications

March 2006

\title{
Use of a modified zirconia support in the separation of immunoproteins
}

Anuradha Subramanian

Department of chemical Engineering,University of Nebraska Lincoln., asubramanian2@unl.edu

Sabyasachi Sarkar

Department of Chemical and Biomolecular Engineering, University of Nebraska Lincoln

Follow this and additional works at: https://digitalcommons.unl.edu/chemeng_biotechnology

Part of the Biochemical and Biomolecular Engineering Commons

Subramanian, Anuradha and Sarkar, Sabyasachi, "Use of a modified zirconia support in the separation of immunoproteins" (2006). Papers in Biotechnology. 30.

https://digitalcommons.unl.edu/chemeng_biotechnology/30

This Article is brought to you for free and open access by the Chemical and Biomolecular Engineering Research and Publications at DigitalCommons@University of Nebraska - Lincoln. It has been accepted for inclusion in Papers in Biotechnology by an authorized administrator of DigitalCommons@University of Nebraska - Lincoln. 
Economics, efficiency and practicality are some of the constraints dictating the search for novel chromatographic supports relevant for use in the in- or large-scale purification of proteins. In this rcgard, affinity chrornatography, ion-exchange chroniatography and other forms of lectrostatic chroinatography that exploit differences in biological specificity or surface charge anisotropy of proteins, have the greatest potential of impacting future trends in scalable protein separation methodologies. Researchmatographic based rediction of illass transport, biological actividustrial ty behavior, kinetic and thermodynamic parameters that impact protein retention and separation are thus essential for the integration of these chromatographic-based unitoperations into the purification scheme. Affinity chromatography uses biological ligands like protein A or biotin-avidin to achieve exquisite specificity and separation. However, Inany of these biological ligands are macromolecular and fragile, expensive to obtain fsoin bacterial or tissue-culture sources and are difficult to ilnmobilize without losing activity. The use of protein A and protein $\mathrm{G}$ in affinity chromatography is also negatively impacted by the harsh elution conditions and pose special challenges regarding regeneration and sanitation [l]. Some of these drawbacks preclude the use of biological ligands in practical and colnmercial applications and this has prompted many researchers to tui11 their attention to the develop nent of synthetic ligands [2]. In contrast, smaller inolecules like dyes, ainino acids, metal ions and chemical moieties show comparable affinities and their specificities can be increased or decreased either at adsorption or desorption to attain resolutions and degrees of purification co nparablet $o$ those of irninunoadsorption [3-131. The effectiveness of a pseudo-biospecific chromatography support that has been synthesized by postderi- 
vatization of zirconia particles with $\mathrm{N}, \mathrm{N}, \mathrm{N} 1, \mathrm{~N} 1-$

ethylenediamietetramethylenephosphonic acid (EDTPA), and termed r-PEZ, for the separations of $i \sim n m u n o g l o b u l i n s f$ rom complex biological fluids has been de nonstrated elsewhere [14]. Although the elution of retained $\lg G$ from both serum and cell culture supematants was effected by inild desorption buffer, not much is known about the tnechanism underlying the selective recognition if inmunoglobulins. While the ionic properties of both the immobilized ligand and the target protein may play an important role, the fact that selective adsorption takes place at or around the isoelectric $\mathrm{pH}$ of $\lg \mathrm{G}$ is of particular interest. The influence of $\mathrm{pH}$, salt concentration and the effect of chaotropic salts have been studied. Additionally, with the aim of an eventual scale-up, a study of kinetic and thermodynamic factors, such as affinity constants and adsolption rate constants, of this adsorption was undertaken.

\section{Materials and methods}

\subsection{Reagents}

All cheinicals were of analytical-grade or better. Sodium chloride was purchased from Fischer (Hanover Park, IL, USA). EDTPA was purchased from TCl America (Portland, OR, USA). Bovine serum albumin (BSA), pure human immunoglobulin $G$ (hlgG), all horseradish peroxidase conjugated antiiminunoglobulins used for enzyme-linked iinmunosorbent assay (ELISA) and human serum albumin (HSA) were obtained froin Sigma (St. Louis, MO, USA). All proteins were used without further purification. Human iinmunoglobulin $A(h / g A)$ and hurnan iinmunoglobulin $M(\mathrm{hlgM})$ were purchased from Jackson Immunoresearch (West Grove, PA, USA). Protein A-hypes D column was purchased froin Sigma. Zir- 
chrom (Anoka, MN, USA) provided the prepacked r-PEZ columns. Immulon I1 microtiter plates were purchased from Fisher. Affinity pulified goat anti-mouse (whole molecule) immunoglobulins and goat anti-mouse iinmunoglobulins conjugated to horseradish peroxidase (HRP) were purchased from Sigma. o-Phenylenediainine. $2 \mathrm{HCl}$ (OPD) tablets were purchased froin Abbott Labs. (Chicago, IL, USA). Precast NuPage 4-12\% Bis-Tris gels were purchased from Invitrogen (Carlsbad, CA, USA). A Genesys 5 inodel from Spectronic Instruments UVvisible spectrophotometer (Rochester, NY, USA) was used to record the adsorption measurements. A benchtop microcentrifuge (Eppendorf Centrifuge 5415C) was used to sediment the r-PEZ particles for batch experiments.

\subsection{Kinetic binding experiment}

A small-scale kinetic experiment was conducted to obtain binding kinetics data. Approximately $0.4 \mathrm{~m} 1$ of a $50 \%(\mathrm{v} / \mathrm{v})$ sluriy $\mathrm{r}$ PEZ and loading buffer was transferred into 5.0-m1 plastic test tubes to yield approximately 200 p. 1 of beads. The beads were allowed to settle for at least $5 \mathrm{~min}$ and the liquid overlay was then pipetted off. A samples olution of hlgG at a concentration of $1.0 \mathrm{mg} / \mathrm{ml}$ was prepared in $20 \mathrm{rnM} 2-(\mathrm{N}-$ morpholino)ethanesulfonic acid (MES), 4 mM EDTPA, 50 nIM NaC1, pH 5.5 (further refewed to as LB). A 3.0-1111 volume of this solution was added to the each tube. Tubes were placed on an end-to-end rotator and allowed to rotate for $24 \mathrm{~h}$ at 4 "C. Aliquots were taken at times equal to $0.5,1$, $5,10,20,30,45,60,120,240$ inin and 24 h. hnmunoglobulin concentrations were measured by measuring the absorbance at $280 \mathrm{~nm}$. 
2.3. Determiriation of dissociation constant, $K$, and dynamic bead capacity

For this study, a solution of pure hIgG in LB was used. This proten solution was added to the column, which was equilibrated with the loading buffer, at concentrations of hIgG ranging at 0.5 and finear velocities of $3.01-48.19 \mathrm{~cm} / \mathrm{min}$. The absorbance of the effluent at $280 \mathrm{~nm}$ was monitored continuously. The injection was continued until the absorbance of the effluent reached $80 \%$ of the inlet concentration. The column was then washed with loading buffer until the absorbance at $280 \mathrm{~nm}$ reached the baseline. The adsorbed hIgG was then eluted with the $20 \mathrm{mM}$ MES, $4 \mathrm{~m} M$ EDTPA, $1.0 \mathrm{M} \mathrm{NaCl}$, pH 5.5 (further referred to as EB) For each linear velocity the dynamic capacity of the column was determined as the amount of hIgG maintained per milliliter of bead.

\subsection{Deternzination of adsorption rate constants}

This experiment was done by using the split-peak approach as described elsewhere [15]. For this experiment a $0.83-\mathrm{m} 1$ column equilibrated with LB. A $30-\mathrm{ml}$ volume of a $2.0 \mathrm{mg} / \mathrm{ml}$ solution of $\mathrm{hIgG}$ was prepared in LB. Aliquots of 1 nil were consecutively injected into the column. Unabsorbed protein was collected for each aliquot injected giving a total of ten fractions collected for a particular linear velocity. In each peak the total amount of protein was determined by measuring absorbance at OD 280 $\mathrm{nm}$. After all ten $1-\mathrm{ml}$ aliquots were injected the retained protein was eluted and absorbance was measured at $280 \mathrm{~nm}$.

\subsection{Identification of the binding site}

It is important to determine whether hIgG was bound to $r_{-} \mathrm{PEZ}$ at the $\mathrm{F}$, or $\mathrm{F}$,, or $\mathrm{F}_{(\mathrm{ab}) 2}$. Antibody fragments $\left[\mathrm{F}\right.$, or $\mathrm{F}$, or $\left.\mathrm{F}_{(\mathrm{ab}) 2}\right]$ were purchased commercially or prepared by enzymatic hydrolysis of hIgG using commercially available pepsin and papain kits from Pierce. Antibody fragments were chromatographed separately under identical conditions, as used for IgG retention and elution protocol as described earlier. The column-wash and elution fractions were assayed by specific ELISA assays
[16]. The total recovery and yield of each fragment was assessed quantitatively.

In a separate experiment, $2.0-\mathrm{m} 1$ protein $\mathrm{A}$ immobilized on a hyper D support was packed into a Pharmacia column and antibody fragments were chromatographed according to the manufacturer's instructions. In a typical application, 1-m1 of antibody fragment solution was diluted with $1.0 \mathrm{ml}$ of $0.5 \mathrm{M}$ sodium citrate buffer at $\mathrm{pH} 8.4(\mathrm{LB}$,$) . Feed$ was filtered using a Millipore $0.45-\mu \mathrm{m}$ membrane filter and loaded on to the column at a linear velocity of $1.0 \mathrm{~cm} / \mathrm{min}$. Loosely bound proteins were washed with LB,. The elution of the bound monoclonal antibody $(\mathrm{mAb})$ was effected with $0.5 \%$ acetic acid. The $\mathrm{pH}$ of the elution fraction was immediately raised to 7.0 with $1 \mathrm{M}$ Tris base. All chromatographic fractions were saved and analyzed for total protein content at an absorbance of $280 \mathrm{~nm}$ and specific antibody fragment content by specific ELISA assays.

\subsection{Detection of IgG fragments by ELISA assays}

Immulon II microtiter plates were incubated with $100 \mu \mathrm{l} /$ well of $5 \mu \mathrm{g} / \mathrm{ml}$ rabbit anti-human Fab specific antisera coating buffer $\left(0.1 \mathrm{M} \mathrm{NaHCO}_{3}, 0.1\right.$ $\mathrm{M} \mathrm{NaCl}, \mathrm{pH} 9.3$ ) for $24 \mathrm{~h}$ at 4 "C. Wells were washed with washing buffer $(50 \mathrm{mM} \mathrm{NaCl}, 20 \mathrm{mM}$ Tris- $\mathrm{HCl}, 0.05 \%$ Tween, $\mathrm{pH}$ 7.2) and residual sites were blocked with blocking/dilution buffer $(50 \mathrm{~m} M$ $\mathrm{NaCl}, 20 \mathrm{~m} M$ Tris- $\mathrm{HCl}, 0.5 \%$ casein, $\mathrm{pH} 7.2$ ) for 30 min at room temperature. A $100 \mu \mu l$ volume of diluted standard and samples in blocking/dilution buffer were added to the each well and incubated for $30 \mathrm{~min}$ at 37 "C. After incubation wells were washed three tiines with washing buffer and $100 \mu \mathrm{l} /$ well of 1:2500 diluted HRP conjugated rabbit anti-human IgG was added to each well and incubated at $37^{\circ} \mathrm{C}$ for $30 \mathrm{~min}$. Wells were washed three times and 100 $\mu \mathrm{l} /$ well of OPD substrate was added. The colorimetric reaction was stopped after approximately $3 \mathrm{~min}$ by the addition of $100 \mu \mathrm{l} /$ well of $1.5 \mathrm{M}$ sulfuric acid. Bound chromophore was detected using a BioTek microplate ELISA reader at $490 \mathrm{~nm}$.

A similar ELISA procedure was used for the determination of $\mathrm{F}$, and $\mathrm{Fc}$ and with the following changes. The plates were coated with $100 \mu \mathrm{l} /$ well of 
$5 \mu \mathrm{g} / \mathrm{ml}$ goat anti-human $\mathrm{F}_{(\mathrm{ab}) 2}$ and $\mathrm{F}$, specific antisera, for $\mathrm{F}_{(\mathrm{ab}) 2}$ and $\mathrm{F}$, determination, respectively.

\section{Results}

\subsection{Effect of temperature on the binding of $h \operatorname{Ig} G$ to $r$ PEZ}

Static binding experiments were conducted to determine the effect of temperature on the binding of hIgG to r_PEZ. The teniperature does not seem to have any significant effect on the binding capacities of hIgG to r_PEZ, as observed from the similar shapes of the isotherms [14]. The maximum static binding capacity $(\mathrm{Q},,,$,$) was found to range from 47$ to $51 \mathrm{mg} \mathrm{hIgG}$ bound per $\mathrm{ml}$ of beads. The $\mathrm{K}$, values were found to range from $4.13 \cdot 10^{-6}$ to $5.67 \cdot 10^{-6} \mathrm{M}$ [moles of hIgG bound per liter of (wet) $r_{-}$PEZ beads].

In order to determine whether there were any cooperative effects due to protein-protein interaction during the adsorption process, the isotherm data (from static experiments) were analyzed by a Hill plot using the transfoniied Langmuir equation [17] (Fig. 1. A cooperativity coefficient (n) of unity indicates no cooperativity. Analysis of the isotherms at 4, 10, 22 and 35 "C indicated $n$ values of 0.82 , $1.10,1.10$ and 0.97 , respectively, which suggests that there is no cooperativity due to protein-protein interactions.

\subsection{Kinetic experiment}

Fig. 2 shows the rate of disappearance of $\mathrm{hIgG}$ from solution. Analysis of hIgG concentrations, for all time points, was estimated by hIgG ELISA. Since the experiment was conducted as a closed system it is assumed that all $\mathrm{hIgG}$ measured not in solution is bound to the support. Maximum hIgG retention was observed at $24 \mathrm{~h}$ with $93 \%$ disappearance of protein from solution from an initial hIgG concentration of 1 $\mathrm{mg} / \mathrm{ml}$. The largest percent of hIgG disappearance, or greatest adsorption rate, occurs within the first 5 min of the batch experiment. Of the total equilibrium binding $50 \%$ has occurred by $5.7 \mathrm{~min}$, when $C_{0}$ equals $1.0 \mathrm{mg} / \mathrm{ml}$. At $12 \mathrm{~min}$ approximately $80 \%$ of

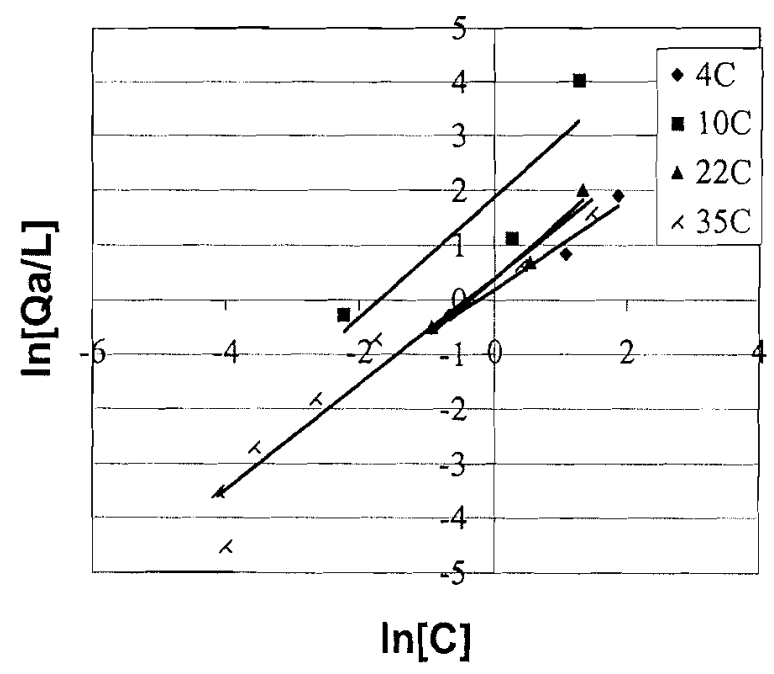

Fig. I. Determination of the protein interaction cooperativity (Hill plot of the data). Data was analyzed by the transfomied Langmuir equation, In $\left[Q_{\mathrm{a}} / L\right]=$ In $K_{\mathrm{a}}+n$ In $\mathrm{C}$; where $\mathrm{L}=Q_{\mathrm{x}}-Q_{\mathrm{a}}$ is the equilibrium free ligand concentration and $n$ the cooperativity coefficient. The value $\mathrm{n}$ was obtained from the slope of tlie linear plot of $\operatorname{In}\left[Q_{\mathrm{a}} / L\right]$ versus In $C$.

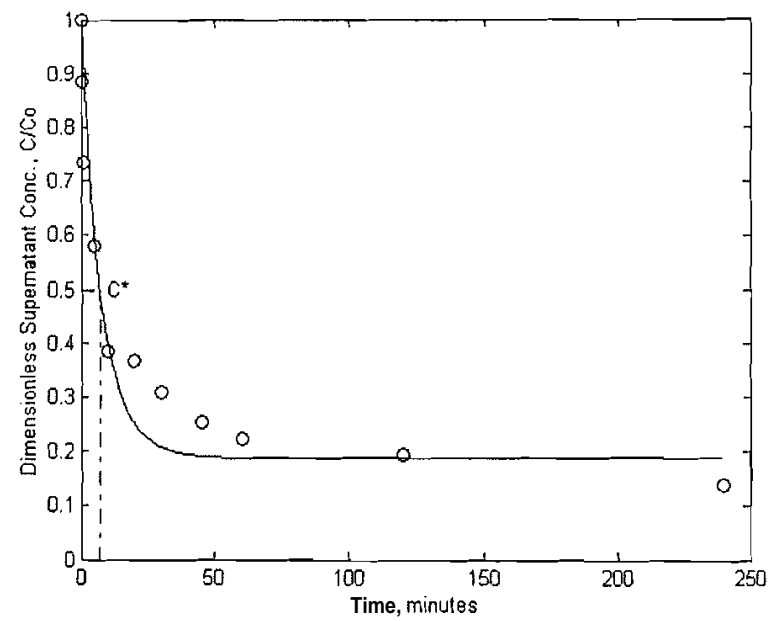

Fig. 2. Batch adsorption profile for the uptake of hIgG by Ligosep Alpha beads. The open circles indicate the experimental data, and the solid lines were calculated by the kinetic rate constant model. Ligosep Alpha beads were contacted with hIgG solution as described in tlie methods section. The supernatant was analyzed at different time intervals for the residual $\mathrm{hIgG}$ concentration. The data were normalized with respect to the $\mathrm{hIgG}$ concentration at time $t=0$. Experiments were done in duplicate and the standard deviation was less than $8 \%$. C* designates the time required to reach $50 \%$ of the initial concentration. 
total binding has occurred according to our experimental data with $90 \%$ having occurred at $50 \mathrm{~min}$.

The experimental data for the protein adsorption obtained under static conditions was compared to the kinetic rate constant model discussed in detail elsewhere [18]. The only unknown parameter was the forward rate constant $\left(k_{1}\right)$, whereas the isotherm

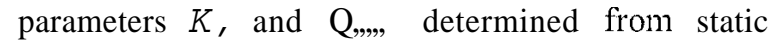
binding experiments were used and the reverse rate constant $\left(k_{2}\right)$ was equated to $K, . k_{1}$. The simulation was run with a variety of values of the unknown parameter $\mathrm{k}$, and the value that gave the best fit to the experimental data was reported. The agreement between the experimental data and simulation is shown in Fig. 3. A $k_{1}$ value of $0.024 \mathrm{~min}^{-1}$ and a $k_{2}$ value of $0.017 \mathrm{~min}^{-1}$ was obtained, respectively.

\subsection{Determination of the dynamic capacity}

Fig. 3 shows the dynamic isotherm at a linear velocity of $12.04 \mathrm{~cm} / \mathrm{min}$ and similar profiles were obtained at other linear velocities studied. The , isotherm shapes indicate Langmuir-type adsorption and the dynamic bead capacity $\left(Q_{x}\right)$ was obtained by Scatchard analyses. The effect; of $\mathrm{Q}_{\mathrm{x}}$ on $\mathrm{r}_{-} \mathrm{PEZ}$ beads as a function of linear velocity is shown in Table 1. A dynamic hIgG adsorption capacity of $20.00,1385$ and $11.53 \mathrm{mg} / \mathrm{ml}$ bead was obtained at linear velocities of $3.01,6.02$ and $12.04 \mathrm{~cm} / \mathrm{min}$, respectively.

\subsection{Determination of the adsorption rate constant}

Fig. 4 shows the effect of the linear velocity on the adsorption rate constant. An association rate constant- $\left(k_{\mathrm{a}}\right)$ of $982.48,1731.65$ and 3242.491 $\mathrm{mol}^{-} \mathrm{s}$ was obtained for linear velocities of 3.0 , 6.0 and $12.0 \mathrm{cmlmin}$, respectively. A best fit of the data in Fig. 3 reveals a linear trend for the data described by the equation $k_{\mathrm{a}}=689.12$ (u $)-903.39$, where $k_{\mathrm{a}}$ is the rate constant $\left(1 \mathrm{~mol}^{-1} \mathrm{~s}^{-1}\right)$ and $u$ is the linear velocity $(\mathrm{cm} / \mathrm{min})$, gives a good linear fit with an $R^{2}$ value of 0.994 within the range tested.

\subsection{Effects of'adsorption rate at varying linear velocities}

The effect of hIgG feed concentration on the adsorption rate of hIgG on $r_{-}$PEZ was evaluated as a
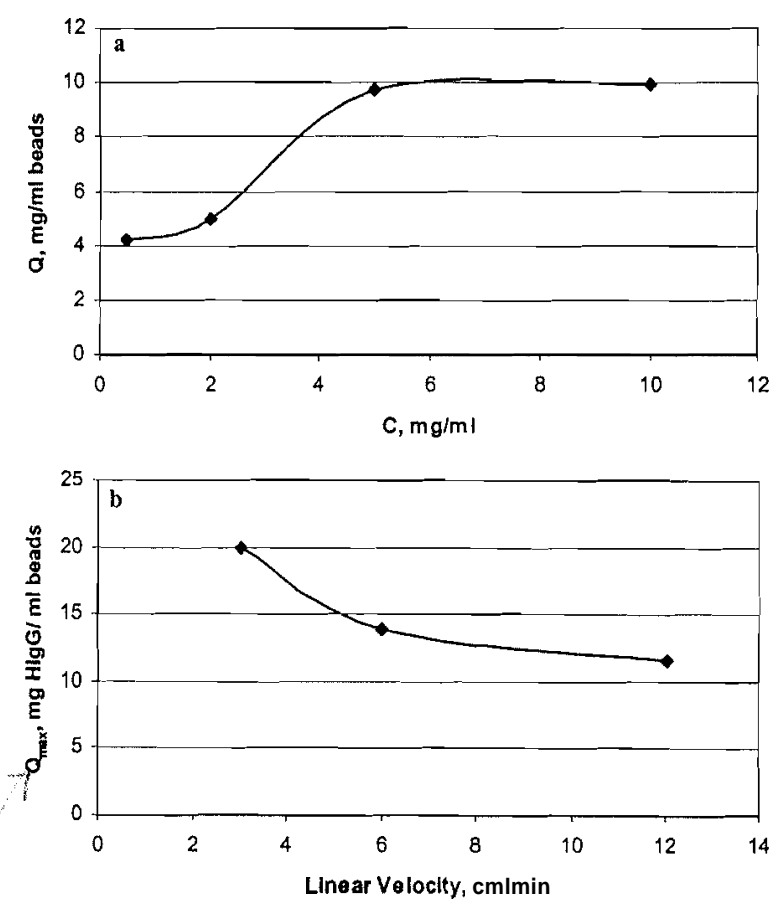

Fig. 3. (a,b) Solution of pure $\mathrm{hIgG}$ at concentrations ranging from 0.5 to $25 \mathrm{mg} / \mathrm{ml}$ was continuously fed to the column until the absorbance of the effluent reached $0.8-0.97$ of the inlet concentration. The column was then washed with loading buffer and the adsorbed hlgG was eluted. For each concentration the dynamic capacity of the column was determined as the amount of hIgG maintained per milliliter of bead. Separate experiments were carried out at linear velocities of 3.01 .6 .02 and $12.04 \mathrm{~cm} / \mathrm{min}$.

function of linear velocities. The adsorption rate increases with increasing $\mathrm{hIgG}$ feed concentration and linear velocity. Empirical equations that relate the adsorption rate changes with feed concentration at linear velocities of $1.1,3.0,5.6$ and $9.0 \mathrm{~cm} / \mathrm{min}$ are shown in Table 2. The adsorption rate is the highest at the highest experimental feed concentration of $10 \mathrm{mg} \mathrm{hIgG/ml}$, more than twenty times than that of the lowest concentration at $0.5 \mathrm{mg}$ $\mathrm{hIgG} / \mathrm{ml}$.

\subsection{Estimation $\Delta H_{\mathrm{o}}$ and AS, of adsorption and comparison with literature}

The thermodynamic parameters for the adsorption can be obtained by determining $\mathrm{K}$, at different temperatures. The dependence of $\mathrm{K}$, as a function of temperature was evaluated from the Langmuirian 
Percent total recovery and yield of antibody fragments on $\mathbf{r}_{-}$PEZ and protein-A column. $\mathbf{r}_{-}$PEZ were challenged with pure antibody fragments $\left(F\right.$, or $F_{a b}$ or F,",,) as separate experiments. Chromatographic fractions were assayed for the specific fragment content by ELISA assays, as detailed in Materials and methods. In general, an average of triplicate application of three different dilutions in ELISA were used for yield calculations

\begin{tabular}{|c|c|c|c|c|c|c|c|c|c|c|}
\hline & & \multicolumn{3}{|c|}{ Fragment $\mathrm{F}$, } & \multicolumn{3}{|c|}{ Fragment $F_{m,}$} & \multicolumn{3}{|c|}{ Fragment $\mathrm{F}}$, \\
\hline & & $\% \mathrm{TR}$ & $\% \mathrm{Y}$ & {$[\% \mathrm{Y}] /[\% \mathrm{TR}]$} & $\% \mathrm{TR}$ & $\% \mathrm{Y}$ & {$[\% \mathrm{Y}] /[\% \mathrm{TR}]$} & $\% \mathrm{TR}$ & $\% \mathrm{Y}$ & {$[\% \mathrm{Y}] /[\% \mathrm{TR}]$} \\
\hline \multirow[t]{2}{*}{ Protein A } & Run 1 & 88.8 & 85.0 & 0.96 & 91.0 & 0.9 & 0.01 & 97.8 & 0.1 & 0.01 \\
\hline & Run 2 & 92.5 & 88.0 & 0.95 & 83.0 & 2.0 & 0.02 & 94.9 & 1.9 & 0.02 \\
\hline \multirow[t]{2}{*}{$\mathrm{r}_{-} \mathrm{PEZ}$} & Run 1 & 57.5 & 16.3 & 0.28 & 47.5 & 35.8 & 0.75 & 57.3 & 42.0 & 0.73 \\
\hline & Run 2 & 67.5 & 20.0 & 0.30 & 48.0 & 38.0 & 0.79 & 62.5 & 39.1 & 0.63 \\
\hline
\end{tabular}

Percent total recovery (TR) is defined as the ratio of the sum of the total protein in the elutate and column fall-through fractions to the total protein present in the feed. Percent yield (Y) Is defined as the ratio of the IgG present in the eluate fraction to the total amount of IgG in the feed. Fragments were also chromatographed on Protein A-hyper D column according to manufacturer's instructions. The chromatographic fractions were assayed as outlined in Methods.

analyses of the isotherm data $[1 l]$. From the Van't Hoff reaction isotherm $\mathrm{AG}=\Delta G^{\circ}-R T \ln [K$,$] ;$ when $\mathrm{AG}=0$, the value of $\Delta G^{\circ}$ can be calculated $\left(\Delta G^{\circ}=R T\right.$ In $\left.[K],\right) . \Delta G^{0}$ can then be calculated at a given temperature from the value of $K$,. The slope of the plot of $\ln [K$,$] versus 1 I T$ yielded AHo, assuming $\mathrm{AH}^{\prime \prime}$ is independent of temperature [19]. A $\Delta H_{\mathrm{o}}$ (adsorption) value of $-5.64 \mathrm{~kJ} / \mathrm{mol}$ and a $\Delta S_{\mathrm{o}}$ (adsorption) value of $120 \mathrm{~kJ} / \mathrm{K}$ were obtained for the interaction of hIgG with r_PEZ.

\subsection{Identification of binding site - $\cos _{e} 1$}

Table 3 lists the total yield and recovery obtained with each IgG fragment, as separate chromatographic experiments. The $\mathrm{F}$, and the $\mathrm{F}_{(\mathrm{ab}) 2}$ fragment were both retained on the r-PEZ column. It appears that the $F$, and $F_{(a b) 2}$ fragments were retained to a similar extent or in other words $r_{-}$PEZ has similar affinity for the $\mathrm{F}$, and $\mathrm{F}_{(\mathrm{ab}) 2}$ fragments. $\mathrm{F}$, fragment was also retained but to a lesser extent. Similar trends and percentages were obtained when the binding of the $\operatorname{IgG}$ fragment were tested under batch conditions (data not included).

In contrast, the $\mathrm{F}$, fragment was quantitatively retained on the protein A column as expected (Table 3). Both $F_{,}$, and $F_{(a b) 2}$ fragments were not retained on the protein A column. Similar trends and percentages were obtained when the binding of the IgG fragment to protein A beads was tested under batch conditions (data not included).

\section{Discussion}

To gain a better understanding of the effect of support characteristics, support activation chemistry on the parameters impacting the binding of immunoglobulins from biological fluids, further studies aimed at understanding the adsorption mechanism and the nature of interactive forces between immunoglobulins and binding site on EDTPA-modified zirconia beads were undertaken. Moreover, with the aim of an eventual scale-up, a study of the kinetic and thermodynamic parameters, such as affinity constants and adsorption rate constants of this interaction was employed.

The success of a chromatographic separation depends upon the biospecific interaction between the protein of interest and the binding site on the stationary phase. All other components in the feed mixture should have little or no affinity for the binding site. To gain a better understanding of the interaction between the protein and the binding site it is often necessary to quantify important factors such as capacity of the affinity matrix and the dissociation constant of the corresponding protein-ligand interaction. These parameters are useful in the scale-up separation of immunoglobulins by process scale 

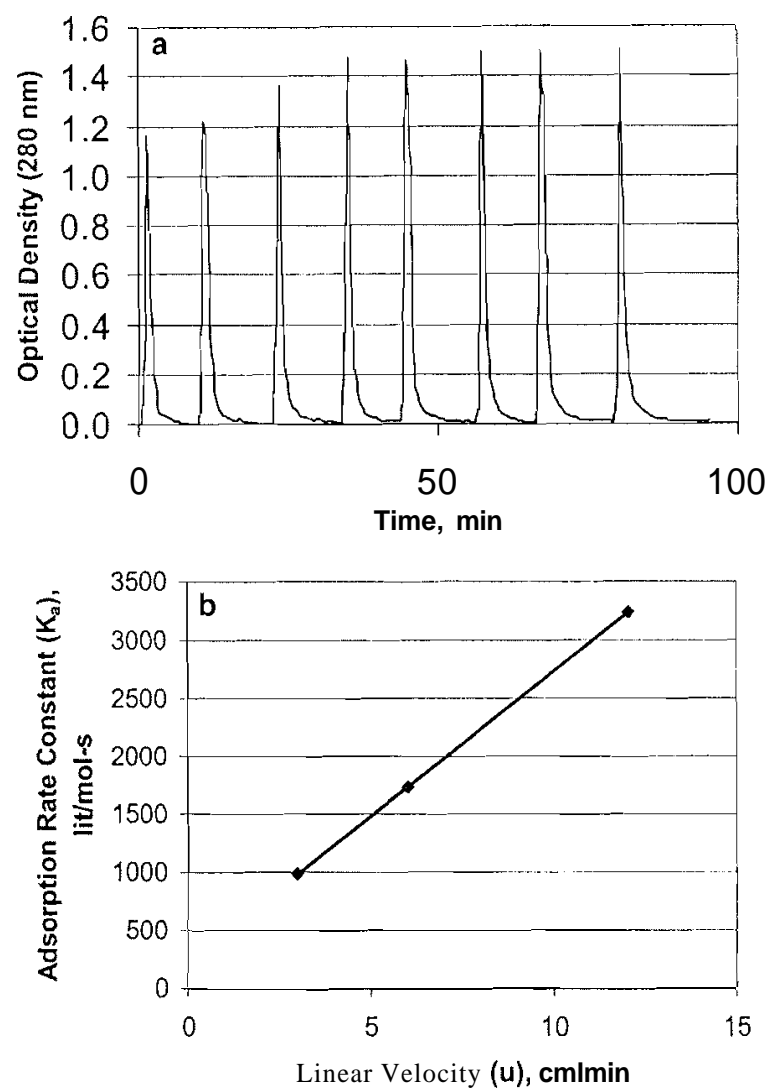

Fig. 4. (a,b) At a given constant linear velocity, 15 aliquots ( $1 \mathrm{ml}$ each) of a $3.5 \mathrm{mg} / \mathrm{ml}$ solution of hIgG were consecutively injected into the column. The cumulative amount of injected protein, and unadsorbed protein was calculated. The ratio of unadsorbed protein to tlie injected protein was expressed as $f$ and $1-\mathbf{f}$ gave tlie adsorption yield. The rate constant $k_{\text {: }}$ was determined from the linear region of the graph and plotted as a function of the linear velocity. Similar experiments were performed at other linear velocities studied $(3.01,6.02$ and $12.04 \mathrm{~cm} / \mathrm{min}$ ).

chromatography. It is therefore useful to study equilibrium adsorption data with the intention of determining how the support reacts to protein binding with increasing concentrations. The shape of the equilibrium adsorption curve at temperatures studied indicates a Langmuir-type isotherm. We hypothesize that at these temperatures, hIgG binds uniformly with a high affinity for the binding sites until it reaches a maximum binding energy. The static capacity of $r$ PEZ as determined by the Langmuir adsorption data was calculated to be $64-87 \mathrm{mg} \operatorname{IgG}$
Table 2

Effect ot the flow-late on the late of adsorptlon The data obtained in Fig $\checkmark 4$ were approximated to the following equation; $\mathrm{AR}=a u+$ $b$ where a and $b$ are constants and $u$ is the linear velocity and AR 1s the adsorptlon rate The adsorption rate $\left(\mathrm{mg} \mathrm{ml}^{\prime} \mathrm{m} / \mathrm{n}^{\prime}\right)$ was calculated as follows: amount of protein retained per $\mathrm{ml}$ of support

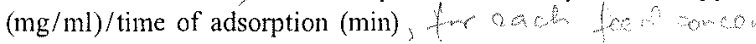

\begin{tabular}{ll}
\hline $\begin{array}{l}\text { Feed } \\
\text { concentration } \\
(\mathrm{mg} / \mathrm{ml})\end{array}$ & $\begin{array}{l}\text { Empirical } \\
\text { equation }\end{array}$ \\
\hline 0.5 & $y=9 \cdot 10^{8} x+2 \cdot 10^{-7}$ \\
2 & $y=3 \cdot 10^{-7} x+8 \cdot 10^{-7}$ \\
5 & $y=1 \cdot 10^{6} x-2 \cdot 10^{-7}$ \\
10 & $y=2 \cdot 10^{6} x-6 \cdot 10^{-8}$ \\
\hline
\end{tabular}

per $\mathrm{ml}$ of beads, which is comparable to that reported for protein A-Sepharose and protein A-Ultragel'. The dissociation constant, $\mathrm{K}$, was determined to be in the range of $1.12 \cdot 10^{-5}$ to $2.4 \cdot 10^{-5} \mathrm{M}$, which indicates medium affinity and is typical for a pseudoaffinity ligand [20].

The high capacity and selectivity displayed by the matrix for immunoglobulins in equilibrium prompted us to study the kinetic aspects of this adsorption for an eventual scale-up of IgG separation from plasma or biological fluids. The values obtained for the dynamic capacity at the experimental linear velocities tested ranged from 9.7 to $18.1 \mathrm{mg}$ IgG per $\mathrm{ml}$ of beads, which again is comparable to the values reported for protein $\mathrm{A}-$ Sepharose and protein $\mathrm{A}-$ Ultragel. The dynamic dissociation constants were in the range of $4 \cdot 10^{-7}$ to $1.6 \cdot 10^{-5} \mathrm{M}$ for the linear velocities tested, indicating weak to medium affinity and consistent with the easy and nondenaturing desorption of bound IgG in column-mode. In the range of velocities tested the dynamic dissociation constant appears to be dependent of linear velocity, increasing with increasing flow-rate until a plateau value at a linear velocity of $5.6 \mathrm{~cm} / \mathrm{min}$ was reached. After which an increase in linear velocity gives no appreciable change in the dissociation constant value.

The adsorption rate constant, $k_{\mathrm{a}}$, as determined by the split-peak method gave a range of values from

\footnotetext{
${ }^{1}$ Technical Handbook, Pierce, Rockford, IL
} 
46.1 to $404.21 \mathrm{~mol}^{-1} \mathrm{~s}^{-1}$ for linear velocities of 1.1 to $9.0 \mathrm{~cm} / \mathrm{min}$, respectively. The linear increase in $k_{\mathrm{a}}$ for the range of velocities tested indicates that the adsorption is velocity dependent and a change in linear velocity will influence $\operatorname{IgG}$ retention. This equation can be utilized in the scale-up separation of immunoglobulins by process scale chromatography with r_PEZ support.

An estimation of the rate of adsorption is also necessary for the design of an automated operation. In our work, the adsorption rate increases with increasing linear velocity. This is in good agreement with our adsorption rate constant results, which follow the same linear trend. Additionally, for the same linear velocity the adsorption rate increases with increasing hIgG feed concentration. This is due to the greater number of $\mathrm{IgG}$ molecules in solution and consequently more in the vicinity of the binding sites. Empirical relationships relating the adsorption rate with linear velocity, $u$, in the form of $\mathrm{AR}=\mathrm{au}+$ $b$ were derived for column-mode hIgG retention and are presented in Table 2. These equations can be used in the scale-up design of hIgG separations.

We postulate that the interactions are governed by a combination of ionic, electrostatic and Van der Waals interactions. We conclude that hydrophobic forces probably play a minor role. It is possible to fine tune the selectivity of $r_{-}$PEZ for a special subset or subclass of $\mathrm{IgG}$, by choosing the appropriate buffer. r_PEZ was found to interact with all the IgG fragments and no preferential interaction with either domain was observed. This finding supports our notion that the interaction between $\mathrm{r}_{-} \mathrm{PEZ}$ and IgG molecule is not based on any bioactive-recognition.

The weak affinity interactions are very advantageous for a high throughput and recovery of labile proteins, like $\operatorname{IgG}$, coinpared with protein A immobilized gels. The high capacity and the reproducibility are attractive features in using such a system for scaling-up operations.

\section{Uncited reference}

[21]

\section{References}

[1] E. Bill, U. Lutz. B. Karlsson, M. Sparman, H. Allgaier, J. Mol. Recognit. 8 (1995) 90.

[2] N. Labrou, Y. Clonis, J. Biotechnol. 36 (1994) 95.

[3] T. Ngo, N. Khatter, J. Chromatogr. 597 (1992) 101.

[4] L. Guerrier, I. Flayeux, A. Schwarz, G. Fassina, E. Boschetti, J. Mol. Recognit. 11 (1998) 107.

[5] G. Fassina, A. Verdoliva, M. Odierna, M. Ruvo. G. Cassini, J. Mol. Recognit. 9 (1996) 564.

[6] G. Fassina, A. Verdoliva, G. Palombo, M. Ruvo, G. Cassani, J. Mol. Recognit. 11 (1998) 128.

[7] G. Palombo, A. Verdoliva, G. Fassina, J. Chromatogr. B 715 (1998) 137.

[8] S. Mandijiny, M. Vijayalakshmi, Biotechnology of Blood Proteins, Coll. INSERM 227 (1993) 189.

[9] A. El-Kak, M. Vijayalakshmi, J. Chromatogr. 570 (1991) 29.

[10] C. Legallais, F. Anspach, S. Bueno, K. Haupt, M. Vijayalakshmi, J. Chromatogr. B 691 (1997) 33.

[11] X. Wu, K. Haupt, M. Vkjayalakshmi, J. Chromatogr. 584 (1992) 35.

[12] S. Bueno, K. Haupt, M. Vijayalakshmi, Inter. J. Art. Org. 18 (1995) 392.

[13] M. Beena, T. Chandy, C. Sharma, J. Biomater. Appl. 8 (1994) 385.

[14] A. Subramanian, S. Sarkar, J. Chromatogr. 944 (2002) 179.

[15] A. El-Kak, S. Manjini, M. Vijayalakshmi, J. Chromatogr. 604 (1992) 29.

[16] A. Subramanian, W.H. Velander, Intl. J. Biochromatogr. 5 (1) (2000) 67.

[17] S. Bueno, K. Haupt, M. Vijayalakshmi, J. Chromatogr. B 667 (1995) 57.

[18] G.L. Skidniore, H.A. Chase, J. Chromatogr. 498 (1990) 113.

[19] G. Fisher, in: A. Schellenberger (Ed.), Enzymkatalyse, Gustav Fisher, Jena, 1990, p. 25.

[20] M. Vijayalakshmi, Trends Biotechnol. 7 (1989) 71.

[21] S. Bueno. K. Haupt, M. Vijayalakshmi, Intl. J. Artif. Organs 18 (1995) 392. 